\title{
Temporal and vertical dynamics in picoplankton photoheterotrophic production in the subtropical North Pacific Ocean
}

\author{
Matthew J. Church ${ }^{1, *}$, Hugh W. Ducklow ${ }^{2}$, Ricardo M. Letelier ${ }^{3}$, David M. Karl ${ }^{1}$ \\ ${ }^{1}$ University of Hawaii, Department of Oceanography, 1000 Pope Road, Honolulu, Hawaii 96822, USA \\ ${ }^{2}$ School of Marine Science, College of William and Mary, PO Box 1346, Gloucester Point, Virginia 23062, USA \\ ${ }^{3}$ College of Oceanic and Atmospheric Sciences, Oregon State University, 104 COAS Administrative Building, Corvallis, \\ Oregon 97331, USA
}

\begin{abstract}
Heterotrophic microbial production is a fundamental determinant in the flow of bioelements and energy within the pelagic ecosystems of the open ocean. To characterize the temporal dynamics in rates of heterotrophic picoplankton production (HPP), we examined vertical profiles of ${ }^{3} \mathrm{H}$-leucine $\left({ }^{3} \mathrm{H}-\mathrm{leu}\right)$ and [methyl- $\left.{ }^{3} \mathrm{H}\right]$-thymidine $\left({ }^{3} \mathrm{H}-\mathrm{TdR}\right)$ incorporation at Stn ALOHA $\left(22^{\circ} 45^{\prime} \mathrm{N}\right.$, $158^{\circ} \mathrm{W}$ ) in the oligotrophic North Pacific Ocean. Euphotic zone rates of ${ }^{3} \mathrm{H}$-leu and ${ }^{3} \mathrm{H}-\mathrm{TdR}$ incorporation were measured in situ under light and dark conditions on cruises to Stn ALOHA between April 2000 and August 2005. Rates of ${ }^{3} \mathrm{H}$-leu and ${ }^{3} \mathrm{H}$-TdR incorporation were elevated in the well-lit upper euphotic zone $(<75 \mathrm{~m})$ and declined with increasing depth. In the mid-euphotic zone (75 to $125 \mathrm{~m})$, where average PAR fluxes declined to $0.6-5 \%$ of the surface irradiance, rates of ${ }^{3} \mathrm{H}-$ leu were significantly greater when samples were incubated at in situ light levels $\left({ }^{3} \mathrm{H}-\mathrm{leu}_{\text {light }}\right)$ than paired in situ incubations kept in the dark $\left({ }^{3} \mathrm{H}-\mathrm{leu}_{\mathrm{dark}}\right)(1$-way ANOVA, $\mathrm{p}<0.05)$. Average rates of photostimulated ${ }^{3} \mathrm{H}$-leu $\left(\Delta \mathrm{Leu}={ }^{3} \mathrm{H}-\mathrm{leu}_{\text {light }}{ }^{3} \mathrm{H}-\mathrm{leu}_{\text {dark }}\right)$ in the upper $125 \mathrm{~m}$ varied between 4.2 and $11 \mathrm{pmol} \mathrm{l}^{-1} \mathrm{~h}^{-1}$, with $\Delta$ Leu approximately equal in magnitude to rates of ${ }^{3} \mathrm{H}-\mathrm{leu}_{\mathrm{dark}}$ between 75 and $125 \mathrm{~m}$. In contrast, rates of ${ }^{3} \mathrm{H}$-TdR did not display a similar sunlight enhancement, with rates of ${ }^{3} \mathrm{H}-\mathrm{TdR}_{\text {light }}$ and ${ }^{3} \mathrm{H}-\mathrm{TdR}$ dark $n$ ot significantly different (1-way ANOVA, p > 0.05). Both ${ }^{3} \mathrm{H}-\mathrm{leu}$ and ${ }^{3} \mathrm{H}$-TdR displayed similar temporal variability, but neither proxy for HPP was correlated to measured rates of primary production. These observations provide the first examination of the temporal dynamics in HPP at Stn ALOHA, and lend insight into the potential importance of photoheterotrophic growth by Prochlorococcus spp. Although organic matter utilization by Prochlorococcus spp. has been documented previously, this is the first study to evaluate their potential role in secondary production of the oceanic ecosystem.
\end{abstract}

KEY WORDS: Picoplankton production · Oligotrophic $\cdot$ North Pacific Ocean $\cdot$ Photoheterotrophy

\section{INTRODUCTION}

A central goal in studies of ocean carbon cycling is to understand how plankton growth influences ecosystem productivity and elemental cycles. In oligotrophic ocean gyres, diverse assemblages of picoplankton ( $\leq 2 \mu \mathrm{m}$ in diameter) comprise a dominant (>70\%) fraction of total plankton biomass (Li et al. 1983, 1992, Fuhrman et al. 1989, Caron et al. 1995, Gasol et al. 1997, Zubkov et al. 2000, Laws 2003). These picoplankton assemblages constitute important linkages in microbial food webs, and are responsible for a majority of carbon metabolism, nutrient regeneration, and energy flow in open ocean ecosystems (Pomeroy 1974, Azam et al. 1983, Ducklow 1983, Goldman 1988).

Since 1988, the 'Hawaii Ocean Time-series' (HOT) program has monitored biological, chemical, and physical oceanographic conditions in the subtropical North Pacific Ocean at Stn ALOHA $\left(22^{\circ} 45^{\prime} \mathrm{N}, 158^{\circ} \mathrm{W}\right)$ for the purposes of characterizing and understanding 
the processes controlling ocean carbon cycling over time scales ranging from seasonal to decadal. The use of time series measurements to constrain rates of plankton production at both Stn ALOHA and the 'Bermuda Atlantic Time-series Study' (BATS) have increased our understanding of ecosystem variability in open ocean ecosystems (Michaels et al. 1994, Carlson \& Ducklow 1996, Karl et al. 1996, Letelier et al. 1996). At Stn ALOHA, photoautotrophic biomass (chlorophyll a [chl a]) is low $\left(<1 \mathrm{mg} \mathrm{m}^{-3}\right.$ ) and photoautotrophic carbon fixation can be measured as deep as $125 \mathrm{~m}$ (Letelier et al. 1996). Despite considerable efforts to understand temporal variability in photoautotrophic production at Stn ALOHA, the data needed to assess the variability in heterotrophic activity are still limited (Church et al. 2004, Williams et al. 2004).

Several methods have been developed and applied for measuring heterotrophic production in the marine environment; two of the most commonly used techniques are incorporation of [methyl- $\left.{ }^{3} \mathrm{H}\right]$-thymidine $\left({ }^{3} \mathrm{H}\right.$ $\mathrm{TdR})$ and ${ }^{3} \mathrm{H}$-leucine $\left({ }^{3} \mathrm{H}\right.$-leu) into picoplankton biomass. Application of either method requires incubating natural plankton populations with the radiolabeled nucleoside or amino acid and determining the rate of precursor incorporation into DNA ( $\left({ }^{3} \mathrm{H}-\mathrm{TdR}\right)$ or protein $\left({ }^{3} \mathrm{H}-\mathrm{leu}\right)$. Typically, both of these assays of heterotrophic production are conducted in darkened incubation vessels to separate heterotrophic and autotrophic metabolisms; however, the recent discoveries of novel bacterial phototrophic physiologies suggest that diverse groups of marine bacterioplankton might depend on or subsidize their metabolic energy requirements using sunlight (Béjà et al. 2000, 2001, 2002, Kolber et al. 2000, 2001).

In a previous study at Stn ALOHA, we observed that picoplankton incorporation of ${ }^{3} \mathrm{H}$-leu demonstrated a response to irradiance (Church et al. 2004). We attributed the enhancement of ${ }^{3} \mathrm{H}$-leu incorporation by irradiance to heterotrophic assimilation of ${ }^{3} \mathrm{H}-\mathrm{leu}$ by Prochlorococcus spp. Because photoautotrophic biomass at Stn ALOHA is dominated by Prochlorococcus spp., facultative heterotrophy by oxytrophic prokaryotes has the potential to complicate interpretation of heterotrophic productivity assays in this region. In the present study, we further examine time-dependent changes in rates of ${ }^{3} \mathrm{H}$-leu and ${ }^{3} \mathrm{H}$-TdR to assess the processes that control heterotrophic production at Stn ALOHA. The objectives of this work were to evaluate the temporal dynamics of ${ }^{3} \mathrm{H}$-leu and ${ }^{3} \mathrm{H}$-TdR incorporation at Stn ALOHA, and to determine whether timedependent variability in ${ }^{3} \mathrm{H}$-leu and ${ }^{3} \mathrm{H}$-TdR incorporation is attributable to some environmental parameter monitored by the HOT program. In addition, we examined whether rates of ${ }^{3} \mathrm{H}$-TdR demonstrate a photoresponse similar to rates of ${ }^{3} \mathrm{H}$-leu incorporation.

\section{MATERIALS AND METHODS}

Study site and sampling. Depth profiles of ${ }^{3} \mathrm{H}-\mathrm{leu}$ and ${ }^{3} \mathrm{H}$-TdR incorporation were conducted at Stn ALOHA using in situ incubation methods. Incorporation of ${ }^{3} \mathrm{H}$-leu was measured on 15 cruises between April 2000 and August 2005, and rates of ${ }^{3} \mathrm{H}$-TdR incorporation were measured on 7 cruises between May 2002 and August 2005 (see Table 1). Water samples for determination of ${ }^{3} \mathrm{H}$-leu and ${ }^{3} \mathrm{H}$-TdR incorporation were collected into polyvinyl chloride bottles at 8 depths $(5,25,45,75,100,125,150,175 \mathrm{~m})$ using a conductivity-temperature-depth (CTD) rosette sampler. At the beginning of each experiment, whole seawater was collected into acid-cleaned $40 \mathrm{ml}$ polycarbonate centrifuge tubes and inoculated with $20 \mathrm{nmol} \mathrm{l}^{-1}$ final concentration of ${ }^{3} \mathrm{H}$-leu (working solution 7.5 to $9.0 \mathrm{Ci}$ $\mathrm{mmol}^{-1}$; New England Nuclear, NEN460A) or $20 \mathrm{nmol}$ $\mathrm{l}^{-1}{ }^{3} \mathrm{H}-\mathrm{TdR}$ (68 $\mathrm{Ci} \mathrm{mmol}^{-1}$, MP Biomedical). These concentrations of ${ }^{3} \mathrm{H}-\mathrm{leu}$ and ${ }^{3} \mathrm{H}$-TdR were empirically determined to achieve rate saturation in upper ocean incubations in May 2002.

Rates of ${ }^{3} \mathrm{H}$-leu and ${ }^{3} \mathrm{H}$-TdR incorporation were determined from paired light $\left({ }^{3} \mathrm{H}-\mathrm{leu}\right.$ light and ${ }^{3} \mathrm{H}-$ $\left.\mathrm{TdR}_{\text {light }}\right)$ and dark $\left({ }^{3} \mathrm{H}-\mathrm{leu}_{\text {dark }}\right.$ and $\left.{ }^{3} \mathrm{H}-\mathrm{TdR}_{\text {dark }}\right)$ in situ incubations. For each depth, triplicate light and dark incubation treatments, as well as 1 Time zero sample were prepared. Time zero treatments were immediately filtered onto $25 \mathrm{~mm}$ diameter, $0.2 \mu \mathrm{m}$ porosity, mixed cellulose ester filters (Millipore GS) and stored frozen in glass Vacutainers (Beckman-Dickson) until processing in the shore-based laboratory. Subsequent processing of Time zero filters was identical to processing of samples (described below).

${ }^{3} \mathrm{H}$-leu and ${ }^{3} \mathrm{H}$-TdR assays were incubated alongside ${ }^{14} \mathrm{C}$-primary production $\left({ }^{14} \mathrm{C}\right.$-PP) assays on a free-floating in situ array. The inoculated $40 \mathrm{ml}$ polycarbonate tubes were attached to a surface tethered array; triplicate dark treatments were placed in opaque cloth bags and also attached to the array at the appropriate depth; both temperature and pressure in the light and dark treatments were identical. Samples were incubated from dawn to dusk (mean duration $=12.5 \mathrm{~h}$, range 11.5 to $13.5 \mathrm{~h}$ ). To terminate incubations, samples were filtered under subdued light onto $0.2 \mu \mathrm{m}$ mixed cellulose ester filters (Kirchman et al. 1985, Kirchman 2001) and rinsed 3 times with ice-cold $5 \%$ trichloroacetic acid (TCA) and 3 times with ice-cold $80 \%$ ethanol (EtOH) (Ducklow et al. 1992), or stored frozen in glass Vacutainers for processing in the laboratory.

Separation of protein and nucleic acids. Samples from 5 of the cruises were processed following a modification of the Schmidt-Thannhauser procedure as described in Karl (1982). This procedure was designed to separate the cold TCA insoluble materials into 
DNA and protein subfractions. Briefly, the modified Schmidt-Thannhauser procedure involved an initial solubilization of the filters in an ice-cold slurry containing $5 \mathrm{ml}$ of $90 \%$ ice-cold acetone, $2 \mathrm{mg} \mathrm{ml}^{-1}$ RNA, DNA, and protein (as bovine serum albumin), and $10 \mathrm{mg}$ diatomaceous earth as a centrifugation aid. Samples were spun in a refrigerated $\left(2^{\circ} \mathrm{C}\right)$, bench-top centrifuge at $1500 \times g$ for $10 \mathrm{~min}$, the supernatants were removed, and the pellets were washed with $5 \mathrm{ml}$ of ice-cold 5\% TCA. Pellets were vortex mixed and this process was repeated 3 times with $5 \%$ TCA, and 3 times with ice-cold $95 \% \mathrm{EtOH}$. After the third EtOH rinse, samples were dried, and the pellets were resuspended in $2 \mathrm{ml}$ of $5 \%$ TCA and boiled for $30 \mathrm{~min}$ to hydrolyze nucleic acids. The pellet was centrifuged and a $0.5 \mathrm{ml}$ subsample of the TCA supernatant was removed and counted by liquid scintillation for determination of the activity of ${ }^{3} \mathrm{H}$-label incorporated into planktonic DNA. The remaining TCA supernatant was aspirated, and the pellet rinsed an additional 2 times with $95 \% \mathrm{EtOH}$, discarding the supernatant after each rinse. The pellet was then dried and $2 \mathrm{ml}$ of $1 \mathrm{~mol} \mathrm{l}^{-1}$ $\mathrm{NaOH}$ were added to each sample. Samples were incubated at $37^{\circ} \mathrm{C}$ for $18 \mathrm{~h}$ after which the tubes were centrifuged and base solubilized proteins were removed from each tube and placed in scintillation vials for radioactivity counts on either a Packard Tri-Carb 4640 or a Packard Tri Carb 2770 TR/SL liquid scintillation counter (Packard Instruments) using external quench standards and luminescence correction.

Photoautotrophic production, chl $a$, and picoplankton abundances. Estimates of euphotic zone primary production were based on depth profiles of photosynthetic assimilation of $\mathrm{H}^{14} \mathrm{CO}_{3}{ }^{-}$as described in Letelier et al. (1996). Briefly, triplicate $500 \mathrm{ml}$ polycarbonate incubation bottles were filled from 6 depths $(5,25,45$, $75,100,125 \mathrm{~m}$ ) directly from the CTD rosette sampling bottles. Each incubation bottle was carried into a radiation van, and under subdued light 0.05 to $0.1 \mu \mathrm{Ci} \mathrm{ml^{-1 }}$ (final activity) of $\mathrm{NaH}^{14} \mathrm{CO}_{3}$ was added to each bottle. The triplicate bottles were incubated from dusk to dawn on the same in situ array used for the ${ }^{3} \mathrm{H}-l e u$ and ${ }^{3} \mathrm{H}$-TdR assays. At the end of the daylight period, the array was recovered and incubation bottles were transferred to the radiation van for processing. To determine the total ${ }^{14} \mathrm{C}$ activity added to each incubation bottle, $200 \mu \mathrm{l}$ of seawater was withdrawn from each bottle and placed in a scintillation vial containing $500 \mu \mathrm{l}$ of $\beta$-phenylethylamine (Sigma-Aldrich). The remaining sample volume was filtered onto $25 \mathrm{~mm}$ GF/F (Whatman) and frozen until analyses in the laboratory. In the shore based laboratory, filters were acidified with $1 \mathrm{ml}$ of $2 \mathrm{~mol} \mathrm{l}^{-1} \mathrm{HCl}$ and vented for $24 \mathrm{~h}$ to remove ${ }^{14} \mathrm{C}-\mathrm{HCO}_{3}{ }^{-}$, followed by addition of $10 \mathrm{ml}$ Aquasol II scintillation cocktail. Radioactivity was counted using a liquid scintillation counter. Photosynthetic rates were calculated using measured total inorganic carbon concentrations to derive the isotopic dilution of the $\mathrm{H}^{14} \mathrm{CO}_{3}^{-}$into seawater inorganic carbon pools.

Fluorometric determinations of chl a followed the protocol described by Letelier et al. (1996); briefly, $125 \mathrm{ml}$ seawater samples were collected in amber polyethylene bottles from the same hydrocasts as the productivity assays, and plankton biomass was concentrated by vacuum filtration onto $25 \mathrm{~mm}$ diameter GF/F filters (Whatman). Filters were extracted in icecold $100 \%$ acetone, stored at $-20^{\circ} \mathrm{C}$ in the dark for $7 \mathrm{~d}$, and chlorophyll concentrations were determined using a Turner Model AU-10 fluorometer.

Picoplankton cell abundances were determined based on flow cytometry analyses using methods described in Campbell \& Vaulot (1993). Seawater samples collected from the same hydrocasts as the productivity assays were placed in $1 \mathrm{ml}$ Cryovials (Corning) containing $0.02 \mathrm{ml}$ of $10 \%$ paraformaldehyde, quick frozen in liquid nitrogen, and stored at $-80^{\circ} \mathrm{C}$ until analyzed. Samples were thawed and stained for $2 \mathrm{~h}$ with the DNA fluorochrome Hoechst 33342 prior to analysis (Monger \& Landry 1993). Abundances of Prochlorococcus spp., Synechococcus spp., and nonchlorophyll containing picoplankton (heterotrophic Bacteria and Archaea) were determined using a Coulter EPICS or a Beckman-Coulter Epics ALTRA dual laser (1 W $488 \mathrm{~nm}$ and $225 \mathrm{~mW}$ UV) flow cytometer. Data on forward-angle light scatter, side scatter, red fluorescence, orange fluorescence, and blue fluorescence were collected, and particle optical properties were converted to cell abundances using the software CYTOPC (Vaulot 1989).

Light measurements. Measurements of photosynthetically available radiation (PAR) to the surface ocean were determined on the same days that the productivity assays were conducted using a shipboard LICOR (LI-200) pyranometer. Surface light fluxes were binned into $10 \mathrm{~min}$ intervals and integrated over the photoperiod. The depth of distribution of light attenuation in the euphotic zone was determined from vertical profiles of downwelling irradiance using a Biospherical Instruments Profiling Reflectance Radiometer (PRR) as described in Letelier et al. (2004).

Statistical analyses. One-way analysis of variance (ANOVA) was used to determine statistical differences between the light and dark ${ }^{3} \mathrm{H}$-leu and ${ }^{3} \mathrm{H}$-TdR assays. To evaluate the influence of irradiance on ${ }^{3} \mathrm{H}-\mathrm{leu}$ incorporation in the upper ocean, the $\Delta$ Leu $\left({ }^{3} \mathrm{H}-\mathrm{leu}_{\text {light }}-{ }^{3} \mathrm{H}-\right.$ ${ }^{l e u_{\text {dark }}}$ ) incorporation rates were fitted by least-squares linear regression to the photosynthetic model of Platt \& Jassby (1976). Parameterization of optimal rates of $\Delta \mathrm{Leu}\left(\Delta \mathrm{Leu}_{\mathrm{opt}}\right)$ and the irradiance required to saturate 
$\Delta$ Leu $\left(E_{\mathrm{k}}\right)$ were derived as described in Sakshaug et al. (1997). Model II least squares regression analyses were used to identify potential relationships between depthintegrated picoplankton abundances, light, ${ }^{14} \mathrm{C}-\mathrm{PP}$, and rates of ${ }^{3} \mathrm{H}$-leu and ${ }^{3} \mathrm{H}-\mathrm{TdR}$. Statistical differences for all tests were evaluated at the $\mathrm{p}<0.05$ level.

\section{RESULTS}

\section{Physical environment: temperature, mixing, and light}

Samples for this study were collected on 15 separate HOT cruises spanning more than a 5 yr period (2000 to 2005). On those cruises where ${ }^{3} \mathrm{H}$-leu and ${ }^{3} \mathrm{H}$-TdR rates were measured, mixed layer depths (based on the 0.125 density criterion of Monterey \& Levitus (1997) ranged between 22 and $89 \mathrm{~m}$ (Table 1). Upper ocean mixing displayed moderate seasonality typical of Stn ALOHA (Karl \& Lukas 1996), with deepest mixing ( $\sim 80 \mathrm{~m})$ during the winter months and shoaling (21 to $60 \mathrm{~m}$ ) of the mixed layer in the summer and late spring (Table 1). Surface PAR varied by more than a factor of 2 (17.1 to $58.7 \mathrm{~mol}$ quanta $\left.\mathrm{m}^{-2} \mathrm{~d}^{-1}\right)$, consistent with the climatological variance in surface irradiance at Stn ALOHA (Letelier et al. 2004). The depth of the isopleth corresponding to $1 \%$ surface PAR varied between 84 and $119 \mathrm{~m}$, consistently exceeding the depth of the surface mixed layer (Table 1).

Table 1. Upper ocean properties and depth integrated (0 to $175 \mathrm{~m}$ ) picoplankton abundances at Stn ALOHA. Integrated surface PAR measured using LICOR 200 pyranometer and integrated over daylight period; mixed layer depth (MLD) calculated based on 0.125 potential density criterion (Monterey \& Levitus 1997). Non-pig $=$ non-pigmented picoplankton (including Bacteria and Archaea); Pro = Prochlorococcus spp.; Syn = Synechococcus $;$ Peuks = picoeukaryotes; nd = no data available

\begin{tabular}{|c|c|c|c|c|c|c|c|}
\hline $\begin{array}{l}\text { Date } \\
\text { sampled }\end{array}$ & $\begin{array}{l}\text { MLD } \\
(\mathrm{m})\end{array}$ & $\begin{array}{c}\text { Surface PAR } \\
\text { (mol quanta } \\
\mathrm{m}^{-2} \mathrm{~d}^{-1} \text { ) }\end{array}$ & $\begin{array}{c}1 \% \\
\text { PAR } \\
(\mathrm{m})\end{array}$ & Non-pig & $\begin{array}{l}\text { Pro } \\
\left(10^{11} \text { cells }\right.\end{array}$ & $\begin{array}{c}\text { Syn } \\
\mathrm{s}^{-2} \text { ) }\end{array}$ & Peuks \\
\hline Apr 2000 & 52 & 50.2 & 95 & 709 & 193 & 3.1 & 2.1 \\
\hline May 2000 & 31 & 46.3 & 118 & 788 & 278 & 1.3 & 1.5 \\
\hline Jun 2000 & 29 & 58.7 & 84 & 859 & 365 & 1.1 & 1.4 \\
\hline Aug 2000 & 62 & 49.4 & 108 & 639 & 166 & 1.2 & 1.0 \\
\hline Oct 2000 & 70 & 30.6 & 107 & 294 & 129 & 0.69 & 0.70 \\
\hline Mar 2001 & 59 & 43.1 & 119 & 250 & 210 & 2.8 & 1.2 \\
\hline Feb 2002 & 89 & 37.1 & 104 & 366 & 112 & 1.5 & 1.6 \\
\hline Mar 2002 & 87 & 44.7 & 114 & 782 & 193 & 4.6 & 2.8 \\
\hline May 2002 & 22 & 51.9 & 116 & 284 & 154 & 1.3 & 1.3 \\
\hline Oct 2004 & 55 & 24.9 & 104 & 640 & 194 & 1.4 & 1.8 \\
\hline Nov 2004 & 35 & 24.3 & 95 & 615 & 148 & 1.1 & 1.7 \\
\hline Dec 2004 & 85 & 17.1 & 98 & 580 & 174 & 2.2 & 2.8 \\
\hline May 2005 & 40 & 46.5 & 113 & 774 & 72 & 1.9 & 1.6 \\
\hline Jul 2005 & 47 & 56.0 & nd & nd & nd & nd & nd \\
\hline Aug 2005 & 50 & 51.6 & 110 & nd & nd & nd & nd \\
\hline
\end{tabular}

\section{Picoplankton, chl a, and rates of primary production}

Picoplankton abundances (defined as non-pigmented prokaryotes, Prochlorococcus spp., Synechococcus spp., and picoeukaryotes) were typical of the climatological distributions and abundances at Stn ALOHA (Fig. 1). Non-pigmented picoplankton were most abundant in the upper ocean, with cell concentrations averaging $\sim 4 \times 10^{5}$ cells $\mathrm{ml}^{1}$ (Fig. 1A), and declined below the $0.1 \%$ surface PAR isopleth. Prochlorococcus spp. abundance was relatively constant in the upper euphotic zone (averaging $1.3 \times 10^{5}$ cells ml ${ }^{-1}$ ), and declined sharply below the $0.1 \%$ surface PAR isopleth (Fig. 1B). Synechococcus spp. abundance was also relatively constant in the upper euphotic zone (averaging $1.3 \times 10^{3}$ cells $\mathrm{ml}^{-1}$ ), with abundances declining beneath the $0.1 \%$ surface PAR isopleth (Fig. 1C). Depth-integrated abundances of Prochlorococcus spp. and non-pigmented picoplankton both varied approximately 3-fold during this study, while Synechococcus spp. abundances varied $\sim 7$-fold (Table 1).

Concentrations and distributions of chl a appeared typical of the climatology measured at Stn ALOHA, with relatively low concentrations of chl $a$ in the sur-

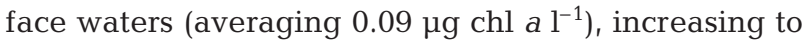
maximum concentrations near the depth of the $1 \%$ surface PAR isopleth (Fig. 2A). On one cruise (June 2000), $\mathrm{chl} a$ in the top $25 \mathrm{~m}$ of the euphotic zone reached con-

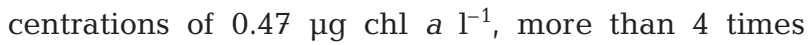
greater than at any other sampling during this study. Coincident with this large increase in near surface chl $a$, PAR attenuation during the June 2000 cruise also increased, resulting in the shallowest euphotic zone $(84 \mathrm{~m})$ on record at Stn ALOHA (Table 1). Temporal dynamics in depth-integrated inventories of chl a varied approximately 2 -fold during this study, also consistent with the climatological variations in chl $a$ at Stn ALOHA (Fig. 2B).

With one notable exception recorded in June 2000, rates of ${ }^{14} \mathrm{C}-\mathrm{PP}$ during this study were typical of the time series climatology at Stn ALOHA. Daytime rates of ${ }^{14} \mathrm{C}$-PP (including the June 2000 sampling) ranged from 22 to $191 \mathrm{nmol} \mathrm{C}^{-1} \mathrm{~h}^{-1}$ in the top $45 \mathrm{~m}$ of the euphotic zone, and from 0.5 to $33 \mathrm{nmol}$ $\mathrm{C}^{-1} \mathrm{~h}^{-1}$ in the lower euphotic zone (75 to $125 \mathrm{~m}$ ) (Fig. 2C). Coincident with the large increase in chl a in June 2000, rates of ${ }^{14} \mathrm{C}$-PP at 5 and $25 \mathrm{~m}$ were 2.9 and and 3.3 times greater than the time-averaged climatological rates at 


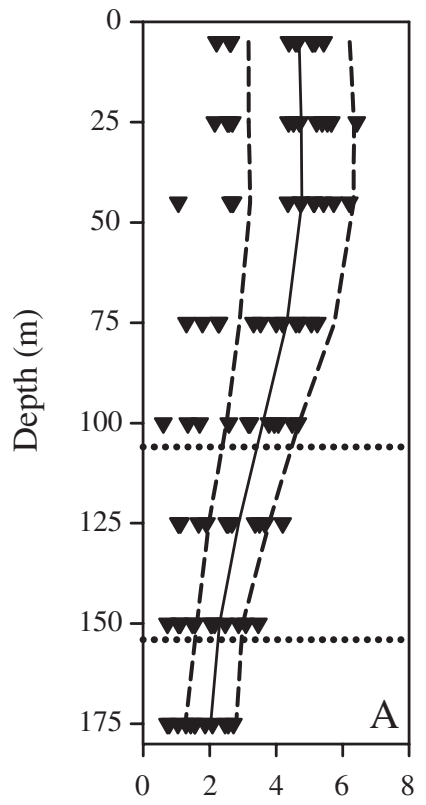

Non-pig. picoplankton (x10 cells ml-1)

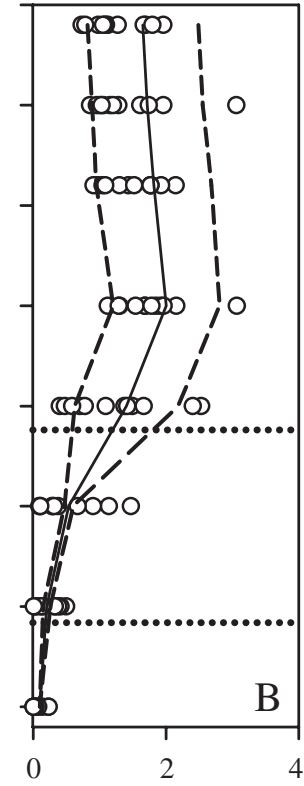

Prochlorococcus $\left(\mathrm{x} 10^{5}\right.$ cells ml-1)

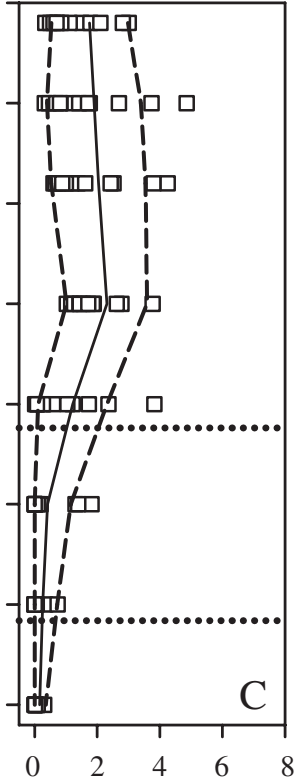

Synechococcus $\left(\mathrm{x} 10^{3}\right.$ cells $\mathrm{ml}^{-1}$ )

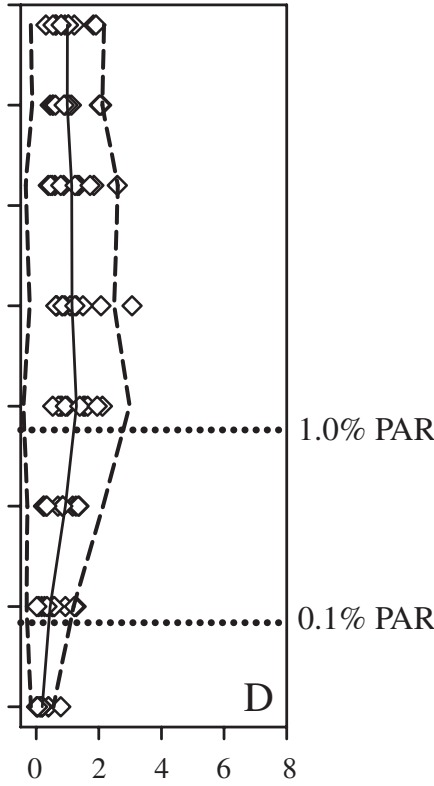

Picoeukaryotes $\left(\mathrm{x} 10^{3}\right.$ cells $\left.\mathrm{ml}^{-1}\right)$

Fig. 1. Vertical profiles of (A) non-pigmented picoplankton, (B) Prochlorococcus spp., (C) Synechococcus spp., and (D) picoeukaryotes in upper ocean at Stn ALOHA during cruises on which ${ }^{3} \mathrm{H}$-leu and ${ }^{3} \mathrm{H}$-TdR assays were conducted. Continuous line = mean time-averaged (1990 to 2002) values; dashed lines = 1 SD of time-averaged means; horizontal dotted lines = timeaveraged (2000 to 2005) 1 and $0.1 \%$ surface PAR isopleths at Stn ALOHA

these depths, respectively (Fig. 2C). Overall, depthintegrated rates of ${ }^{14} \mathrm{C}$-PP varied approximately 4 -fold during this study (1.91 to $\left.8.22 \mathrm{mmol} \mathrm{C} \mathrm{m}^{-2} \mathrm{~h}^{-1}\right)$, with ${ }^{14} \mathrm{C}$-PP averaging $4.1 \pm 1.8 \mathrm{mmol} \mathrm{C} \mathrm{m}^{-2} \mathrm{~h}^{1}$, and peak rates observed in June 2000 when the depth-integrated rate of ${ }^{14} \mathrm{C}$-PP was $85 \%$ greater than ${ }^{14} \mathrm{C}$-PP measured during the remaining part of this study (Fig. 2D).

\section{Rates of ${ }^{3} \mathrm{H}$-leu and ${ }^{3} \mathrm{H}$-TdR incorporation}

The activity (disintegrations $\mathrm{min}^{-1}$ ) of the Time zero blanks measured for each ${ }^{3} \mathrm{H}-\mathrm{leu}$ and ${ }^{3} \mathrm{H}$-TdR assay were always lower than the activity measured in the incubated samples. The ratio of the activity of the Time zero blanks relative to samples ranged between 0.01 and 0.28 (mean $=0.04 \pm 0.05$ ), with the Time zero blanks typically greater in the upper euphotic zone and decreasing with increasing depth, consistent with the general trend in sample activity. Daytime rates of ${ }^{3} \mathrm{H}-\mathrm{leu}$ incorporation were elevated throughout the well-lit portion of the upper euphotic zone and generally declined with increasing depth (Fig. 3A,B). Rates of ${ }^{3} \mathrm{H}$-leu light in the upper $75 \mathrm{~m}$ averaged $29 \mathrm{pmol} \mathrm{l}^{-1}$ $\mathrm{h}^{-1}$, and in the lower euphotic zone $(>100 \mathrm{~m})$ ranged between 2 and $18 \mathrm{pmol} \mathrm{l}^{-1} \mathrm{~h}^{-1}$ (Fig. 3A). Rates of ${ }^{3} \mathrm{H}$ leu $u_{\text {dark }}$ demonstrated temporal and vertical variability similar to ${ }^{3} \mathrm{H}-\mathrm{leu}_{\text {light, }}$ averaging $20 \mathrm{pmol} \mathrm{l}^{-1} \mathrm{~h}^{-1}$ in the upper $75 \mathrm{~m}$ and declining to $2-9 \mathrm{pmol} \mathrm{l}^{-1} \mathrm{~h}^{-1}$ in the deep euphotic zone (Fig. 3B).

One of the most notable features of the vertical profiles of ${ }^{3} \mathrm{H}$-leu incorporation was the photostimulatory response observed throughout the mid-euphotic zone ( 45 to $125 \mathrm{~m}$ ). Between 45 and $125 \mathrm{~m}$, the average rates of ${ }^{3} \mathrm{H}$-leu light $_{\text {were significantly greater }}$ (ANOVA, $\mathrm{p}<$ $0.05)$ than ${ }^{3} \mathrm{H}-$ leu dark. $_{\text {dn }}$. Inis region of the mid-euphotic zone, daily PAR fluxes averaged between 0.21 and 6 mol quanta $\mathrm{m}^{-2} \mathrm{~d}^{-1}$ (equivalent to $0.6-5 \%$ of the surface PAR irradiance) (Fig. 4A). The resulting ratio of ${ }^{3} \mathrm{H}$-leu light ${ }^{3} \mathrm{H}-$ leu $\mathrm{u}_{\text {dark }}$ averaged $1.3 \pm 0.2$ in the upper $25 \mathrm{~m}$ of the euphotic zone, increasing to $1.7 \pm 0.2$ between 45 and $125 \mathrm{~m}$ (Fig. 3C). The resulting depthintegrated $(0$ to $175 \mathrm{~m})$ rates of ${ }^{3} \mathrm{H}$-leu light varied approximately 5 -fold (ranging from 1234 to $6186 \mathrm{nmol}$ ${ }^{3} \mathrm{H}$-leu $\mathrm{m}^{-2} \mathrm{~h}^{-1}$ ) during this study, while areal rates of ${ }^{3} \mathrm{H}$-leu dark $_{\text {varied }} \sim 4$-fold (ranging from 864 to $3427 \mathrm{nmol}^{3} \mathrm{H}$-leu $\mathrm{m}^{-2} \mathrm{~h}^{-1}$ ) (Fig. 5A).

Average rates of the photostimulated component of ${ }^{3} \mathrm{H}$-leu incorporation ( $\Delta$ Leu $={ }^{3} \mathrm{H}$-leu light $-{ }^{3} \mathrm{H}-$ leu $\mathrm{dark}$ ) were not significantly different (1-way ANOVA, $\mathrm{p}>$ 0.05) in the upper $100 \mathrm{~m}$ of the water despite large depth-dependent changes in irradiance (average PAR fluxes varied by 0.69 to $34 \mathrm{~mol}$ quanta $\mathrm{m}^{-2} \mathrm{~d}^{-1}$ ) (Fig. 5A). Below the upper $100 \mathrm{~m}, \Delta$ Leu rates declined with decreasing irradiance (Fig. 4A). Rates of $\Delta$ Leu saturated at light fluxes greater than $\sim 0.6$ mol quanta $\mathrm{m}^{-2} \mathrm{~d}^{-1}$. The 

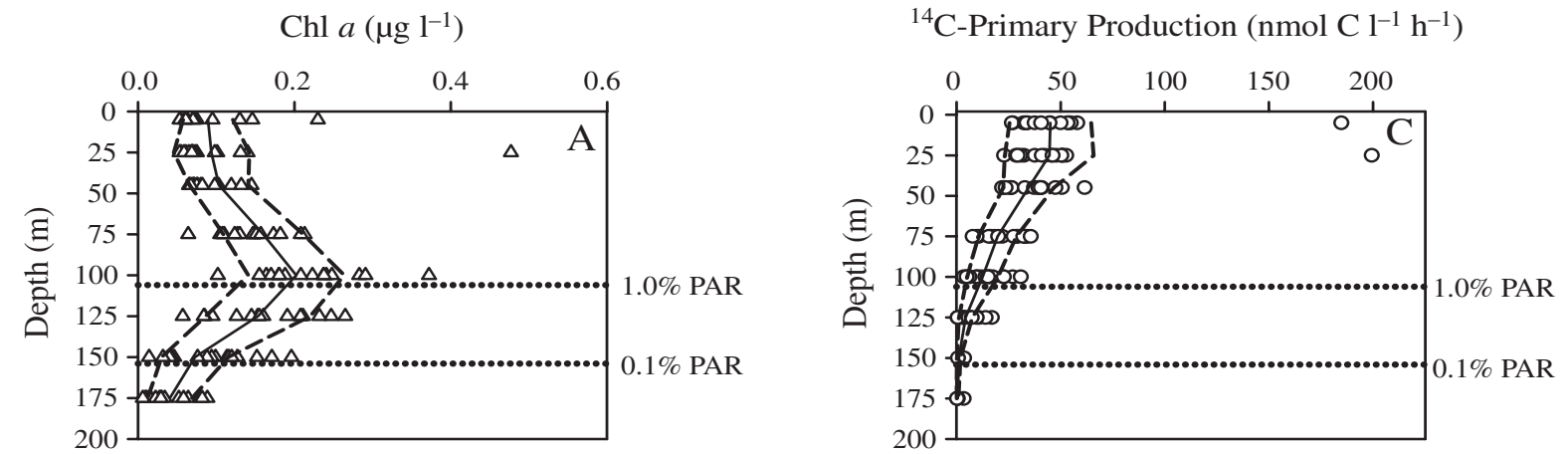

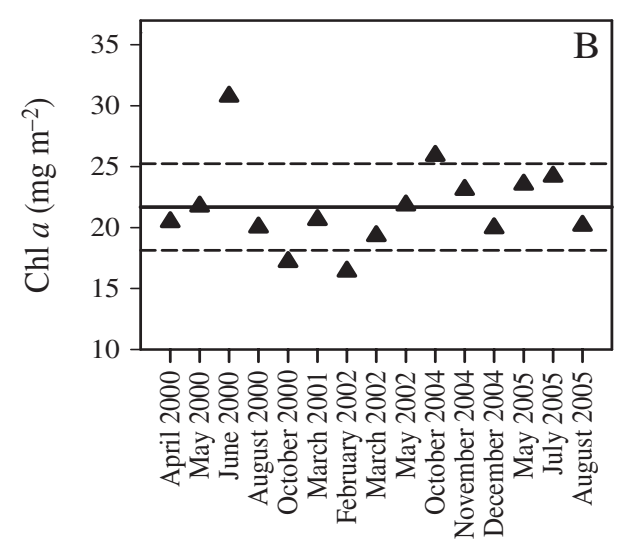

Sampling date

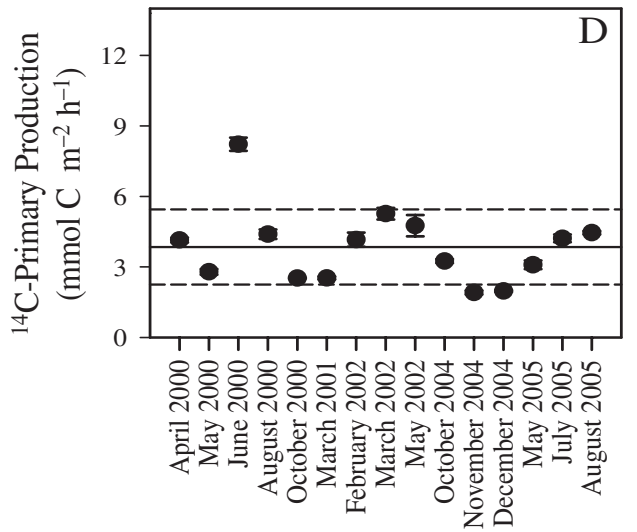

Sampling date

Fig. 2. (A) Vertical distributions of chl a during this study $(\Delta)$; continuous line = time-averaged mean (1989 to 2002) concentrations of chl $a$ at Stn ALOHA; dashed lines = 1 SD of time-averaged mean; horizontal dotted lines = time-averaged (2000 to 2005) 1 and $0.1 \%$ surface PAR isopleths. (B) Depth-integrated (0 to $175 \mathrm{~m})$ inventories of chl a during this study $(\mathbf{\Delta})$; continuous line $=$ time-averaged (1989 to 2004) chl a inventories at Stn ALOHA; dashed lines = 1 SD of time-averaged mean inventories (note that cruise dates are not evenly distributed between April 2000 and August 2005). (C) Vertical profiles of hourly rates of ${ }^{14} \mathrm{C}-\mathrm{PP}$ at Stn ALOHA during this study $(\mathrm{O})$; continuous line = time-averaged mean (1989 to 2002) rate of ${ }^{14} \mathrm{C}-\mathrm{PP}$; dashed lines $=1 \mathrm{SD}$ of timeaveraged mean; horizontal dotted lines = time-averaged (2000 to 2005) 1 and $0.1 \%$ surface PAR isopleths. (D) Depth-integrated $\left(0\right.$ to $175 \mathrm{~m}$ ) rates of ${ }^{14} \mathrm{C}$-PP during this study $(\mathbf{)})$; continuous line = climatological mean $(1989$ to 2004$)$ rate of ${ }^{14} \mathrm{C}$-PP at $\mathrm{Stn}$ $\mathrm{ALOHA}_{\text {; }}$ dashed lines $=1 \mathrm{SD}$ of time-averaged mean rates. Error bars $= \pm \mathrm{SD}$ of monthly depth integrated rates of ${ }^{14} \mathrm{C}-\mathrm{PP}$

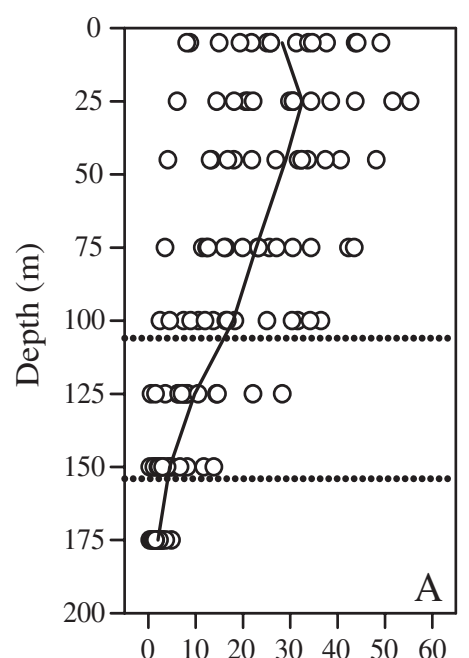

${ }^{3} \mathrm{H}-\mathrm{leu}_{\text {light }}$ incorporation (pmol leu $\mathrm{l}^{-1} \mathrm{~h}^{-1}$ )

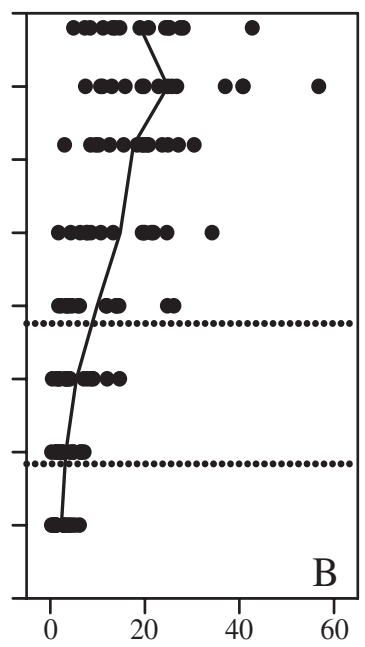

${ }^{3} \mathrm{H}-\mathrm{leu}_{\mathrm{dark}}$ incorporation $\left(\right.$ pmol leu $\mathrm{1}^{-1} \mathrm{~h}^{-1}$ )

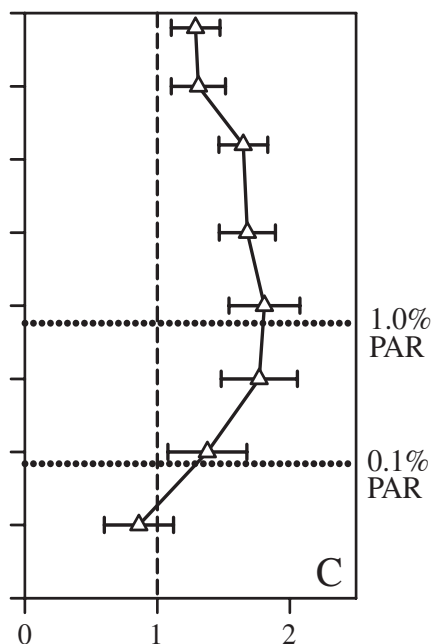

${ }^{3} \mathrm{H}-\mathrm{leu}_{\text {light }}:{ }^{3} \mathrm{H}-\mathrm{leu}_{\text {dark }}$
Fig. 3. Vertical profiles of picoplankton ${ }^{3} \mathrm{H}-\mathrm{leu}$ incorporation rates at Stn ALOHA during the 15 cruises of this study. ${ }^{3} \mathrm{H}-\mathrm{leu}$ incorporation rates from (A) PAR-incubated samples $\left({ }^{3} \mathrm{H}-\right.$ leu light $_{\text {) }}$ and (B) dark-incubated samples $\left({ }^{3} \mathrm{H}-\right.$ leu $\left._{\text {dark }}\right)$; continuous line $=$ mean hourly rate of ${ }^{3} \mathrm{H}$-leu incorporation. (C) Depth profile of mean ratio of ${ }^{3} \mathrm{H}$-leu light: ${ }^{3} \mathrm{H}-\mathrm{leu}_{\mathrm{dark}}$ during this study; error bars $= \pm \mathrm{SE}$ of time-averaged ratio at each depth. Horizontal dotted lines $=$ time averaged (2000 to 2005) 1 and $0.1 \%$ surface PAR isopleths 

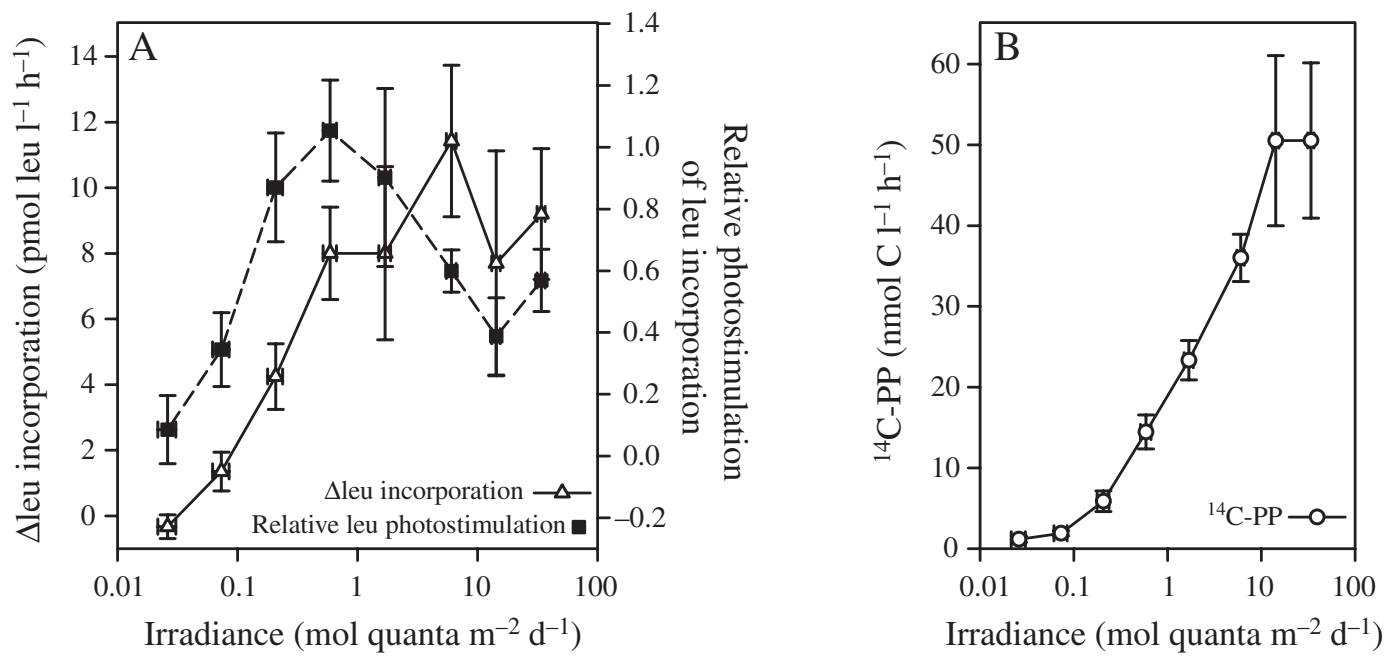

Fig. 4. Relationship of in situ ${ }^{3} \mathrm{H}$-leu incorporation and ${ }^{14} \mathrm{C}$ primary production to irradiance. (A) Time-averaged rates of photostimulated ${ }^{3} \mathrm{H}$-leu incorporation ( $\Delta$ Leu $={ }^{3} \mathrm{H}$-leu light $^{-3} \mathrm{H}$-leu $\mathrm{dark}_{\text {dan }}$ ) and mean relative photostimulation of ${ }^{3} \mathrm{H}$-leu incorporation

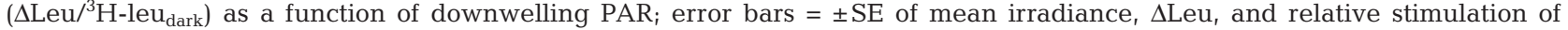
${ }^{3} \mathrm{H}$-leu incorporation. (B) Time-averaged rates of ${ }^{14} \mathrm{C}$-PP measured during this study as a function of downwelling PAR; error bars $= \pm \mathrm{SE}$ of mean irradiance and ${ }^{14} \mathrm{C}-\mathrm{PP}$

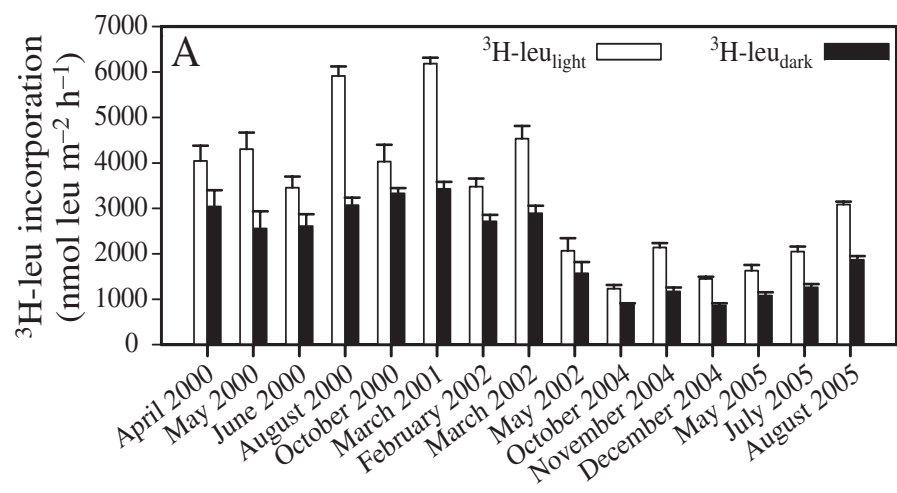

relative stimulation in rates of ${ }^{3} \mathrm{H}$-leu incorporation

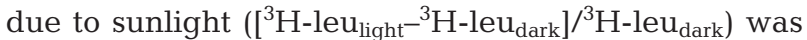
greatest in the mid-euphotic zone, where rates of $\Delta$ Leu were approximately equivalent to ${ }^{3} \mathrm{H}-\mathrm{leu}_{\text {dark }}$ (Fig. 4A). In the lower euphotic zone, rates of ${ }^{14} \mathrm{C}$-PP demonstrated light-dependent patterns similar to those of $\Delta$ Leu, with ${ }^{14} \mathrm{C}$-PP increasing with irradiance. However, in contrast to rates of $\Delta \mathrm{Leu}$, rates of ${ }^{14} \mathrm{C}$-PP in the upper euphotic zone continued to increase with increasing irradiance, saturating above an average light intensity of $\sim 14$ mol quanta $\mathrm{m}^{-2} \mathrm{~d}^{-1}$ (Fig. 4B).

The relationships between in situ rates of $\Delta$ Leu and downwelling PAR fluxes were evaluated based on the model of Platt \& Jassby (1976) describing photosynthesis as a function of irradiance (Table 2). The initial slope $(\alpha)$ of the relationship between in situ $\Delta$ Leu and irradiance varied more than 10 -fold among the cruises (Table 2), while optimal rates of the $\Delta$ Leu incorporation derived from the parameterization of the vertical profiles of $\Delta$ Leu and irradiance $\left(\Delta \mathrm{Leu}_{\mathrm{opt}}\right.$ ) ranged more than 10-fold (1.4 to $34 \mathrm{pmol} \mathrm{l}^{-1} \mathrm{~h}^{1}$ ) (Table 2). These derived rates of $\Delta \mathrm{Leu}_{\mathrm{opt}}$ corresponded to depths varying between 22 and $113 \mathrm{~m}$, and PAR fluxes between 0.34 and 6.2 mol quanta $\mathrm{m}^{-2} \mathrm{~d}^{-1}$ (Table 2).

In contrast to the observed photostimulation of ${ }^{3} \mathrm{H}$ leu, rates of ${ }^{3} \mathrm{H}-\mathrm{TdR}$ incorporation did not reveal a consistent response to sunlight. Rates of ${ }^{3} \mathrm{H}$-TdR incorporation were elevated in the upper $75 \mathrm{~m}$ and typically declined with increasing depth (Fig. 6). Rates of ${ }^{3} \mathrm{H}-$ $\mathrm{TdR}_{\text {light }}$ in the upper portion of the euphotic zone $(<75 \mathrm{~m})$ ranged from 0.12 to $2.5 \mathrm{pmol} \mathrm{TdR} \mathrm{l}^{-1} \mathrm{~h}^{-1}$, while

Fig. 5. Temporal variability in depth-integrated rates of ${ }^{3} \mathrm{H}$-leu and ${ }^{3} \mathrm{H}-\mathrm{TdR}$ at Stn ALOHA. (A) Areal rates of ${ }^{3} \mathrm{H}-\mathrm{leu}_{\text {light }}$ and ${ }^{3} \mathrm{H}-\mathrm{leu}$ dark (B) Depth-integrated ${ }^{3} \mathrm{H}-\mathrm{TdR}_{\text {light }}$ and ${ }^{3} \mathrm{H}-\mathrm{TdR}_{\mathrm{dark}}$ incorporation rates during this study. Error bars = $+1 \mathrm{SD}$ of integrated rates 
Table 2. Photophysiological parameters describing response of photostimulated ${ }^{3} \mathrm{H}$-leucine incorporation ( $\Delta \mathrm{Leu}$ ) to irradiance at Stn ALOHA. Values are regression parameters derived from model of photosynthetic responses to irradiance (see 'Results' for details), with SE of regression derived parameters in parentheses. ${ }^{*}$ Statistically significant $(p<0.05)$ regression derived parameter. $\alpha$ : initial slope; $\Delta \mathrm{Leu}_{\text {opt }}$ : optimal rates of $\Delta \mathrm{Leu}_{;} E_{\mathrm{k}}$ : irradiance required to saturate $\Delta$ Leu

\begin{tabular}{|c|c|c|c|c|}
\hline $\begin{array}{l}\text { Date } \\
\text { sampled }\end{array}$ & $\begin{array}{c}\alpha\left(\mathrm{pmol} \mathrm{leu} \mathrm{l}^{-1}\right. \\
\mathrm{h}^{-1}(\mathrm{~mol} \\
\text { quanta m}^{-2} \\
\left.\left.\mathrm{~d}^{-1}\right)^{-1}\right)\end{array}$ & $\begin{array}{c}\Delta \mathrm{Leu}_{\mathrm{opt}} \\
\left(\mathrm{pmol} \mathrm{leu}^{-1}\right. \\
\left.\mathrm{h}^{-1}\right)\end{array}$ & $\begin{array}{c}E_{\mathrm{k}} \\
\left(\mathrm{mol}_{\text {quanta }}\right. \\
\left.\mathrm{m}^{-2} \mathrm{~d}^{-1}\right)\end{array}$ & $\begin{array}{l}\text { Depth } E_{\mathrm{k}} \\
\text { (m) }\end{array}$ \\
\hline Apr 2000 & $5.9(3.9)$ & $17^{*}(4.2)$ & 0.34 & 103 \\
\hline May 2000 & 21 (19) & $15^{*}(3.4)$ & 1.4 & 89 \\
\hline Jun 2000 & $25(11)$ & $15^{*}(1.9$ & 1.7 & 65 \\
\hline Aug 2000 & $44^{*}(9.2)$ & $34^{*}(1.8)$ & 1.3 & 85 \\
\hline Oct 2000 & $18(14)$ & $18 *(3.2)$ & 0.96 & 80 \\
\hline Mar 2001 & $14^{*}(3.6)$ & $26^{*}(1.8)$ & 0.55 & 113 \\
\hline Feb 2002 & $5.8(3.7)$ & $9.0^{*}(1.6)$ & 0.64 & 92 \\
\hline Mar 2002 & $48(26)$ & $12 *(1.5)$ & 4.0 & 60 \\
\hline May 2002 & $9.0(5.5)$ & $8.0^{*}(1.3)$ & 1.1 & 97 \\
\hline Oct 2004 & $4.0(2.0)$ & $1.4^{*}(0.21)$ & 2.8 & 49 \\
\hline Nov 2004 & 27 (19) & $5.6^{*}(0.93)$ & 4.8 & 33 \\
\hline Dec 2004 & $56(24)$ & $9.0^{*}(0.89)$ & 6.2 & 22 \\
\hline May 2005 & $27(20)$ & $5.6^{*}(1.0)$ & 4.8 & 56 \\
\hline Jul 2005 & $15(6.4)$ & $5.4^{*}(0.63)$ & 2.7 & 72 \\
\hline Aug 2005 & $25(11)$ & $6.8^{*}(0.73)$ & 3.6 & 63 \\
\hline Mean & $27^{*}(7.8)$ & $9.2^{*}(0.64)$ & 2.9 & 61 \\
\hline
\end{tabular}

The majority (>90\%) of ${ }^{3} \mathrm{H}-\mathrm{leu}$ incorporated was retrieved with the base hydrolyzable cellular material, presumably reflecting incorporation of the amino acid into protein. On average, $6 \%$ of the extracted ${ }^{3} \mathrm{H}$-label was retrieved with the hot TCA soluble materials (presumed to be nucleic acid), while the remaining $94 \%$ of the label appeared to separate with cellular protein (Table 3). The relative partitioning of ${ }^{3} \mathrm{H}-\mathrm{leu}$ into the hot TCA and base hydrolyzable material did not demonstrate an apparent dependence on sunlight; however, the percent of the ${ }^{3} \mathrm{H}$ label retrieved with the hot TCA extraction increased with increasing depth in the euphotic zone. Below $125 \mathrm{~m}$ depth, $9 \%$ of the total ${ }^{3} \mathrm{H}$-incorporated label was partitioned into hot TCA soluble cellular subfractions (Table 3).

Extraction of hot TCA soluble and base hydrolyzable ${ }^{3} \mathrm{H}$ cellular constituents from the ${ }^{3} \mathrm{H}-\mathrm{TdR}$ incubations revealed that, on average, $49 \%$ of the

paired rates of $\mathrm{TdR}_{\mathrm{dark}}$ ranged between 0.09 and $3.4 \mathrm{pmol} \mathrm{TdR}^{-1} \mathrm{~h}^{-1}$ (Fig. 6A). Depth-integrated rates of ${ }^{3} \mathrm{H}-\mathrm{TdR}_{\text {light }}$ varied nearly 5 -fold, ranging between 49

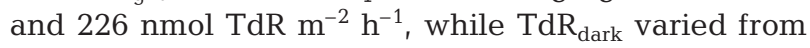
52 to $217 \mathrm{nmol} \mathrm{TdR} \mathrm{m}^{-2} \mathrm{~h}^{-1}$ (Fig. 6B).

${ }^{3} \mathrm{H}-\mathrm{leu}$ and ${ }^{3} \mathrm{H}-\mathrm{TdR}$ depth profiles from 5 cruises (HOT 114, 115, 116, 124, 137) were subjected to a modified Schmidt-Thannhauser protocol to separate the ${ }^{3} \mathrm{H}$ label associated with nucleic acids (hot TCA soluble material) and proteins (base hydrolyzable material).
${ }^{3} \mathrm{H}$-label was associated with hot TCA soluble cellular fractions (presumably DNA), while approximately $51 \%$ of the ${ }^{3} \mathrm{H}$ label was retrieved with the base hydrolyzable material (presumably proteins). ${ }^{3} \mathrm{H}-\mathrm{TdR}$ labeling of acid hydrolyzable material demonstrated dependence on sunlight, with a significantly greater fraction of the ${ }^{3} \mathrm{H}$-label retrieved from acid-insoluble extracts (DNA) when the incubations were conducted in the dark $\left({ }^{3} \mathrm{H}-\mathrm{TdR}_{\mathrm{dark}}\right)$ relative to samples incubated in the light $\left({ }^{3} \mathrm{H}-\mathrm{TdR}_{\text {light }}\right)$ (Table 3$)$.
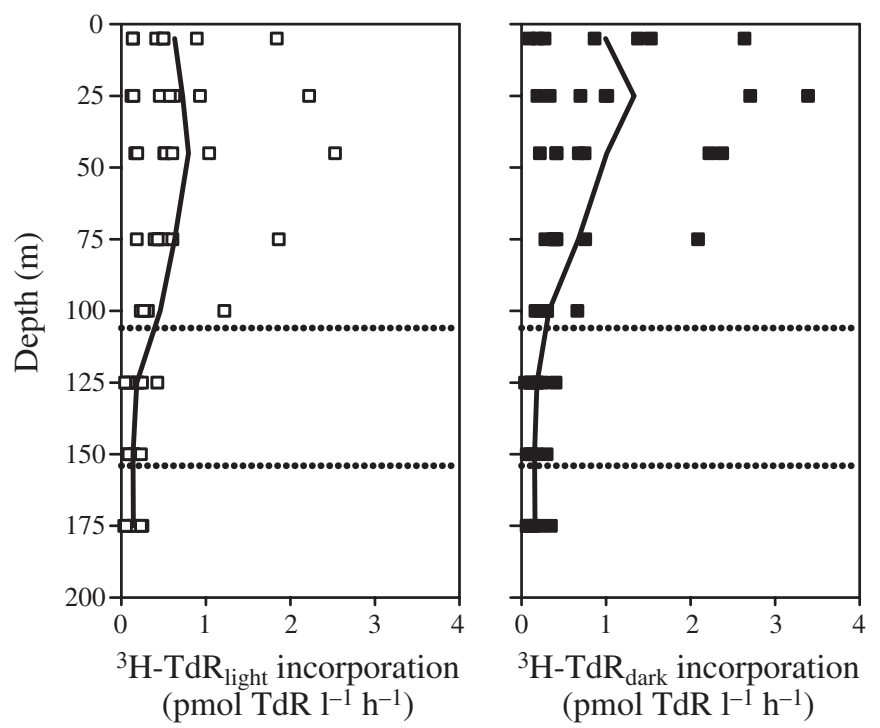

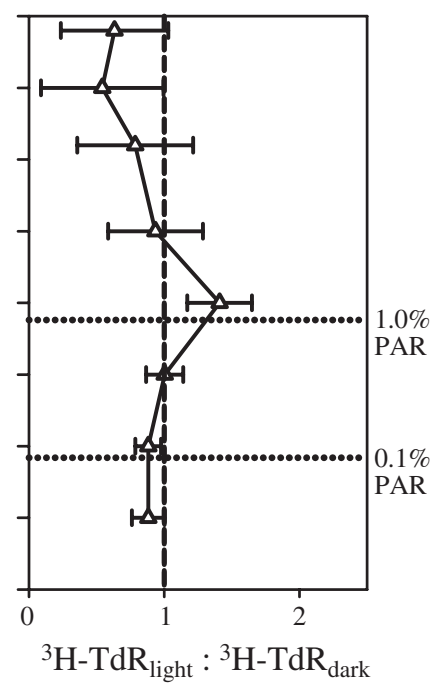

Fig. 6. Vertical profiles of picoplankton ${ }^{3} \mathrm{H}$-TdR incorporation rates during 7 cruises to Stn ALOHA. ${ }^{3} \mathrm{H}-\mathrm{TdR}$ incorporation rates from (A) PAR-incubated samples $\left({ }^{3} \mathrm{H}\right.$ $\mathrm{TdR}_{\text {light }}$ ) and (B) dark-incubated samples $\left({ }^{3} \mathrm{H}-\mathrm{TdR}_{\mathrm{dark}}\right)_{\text {; }}$ continuous line $=$ mean hourly rate derived from the 7 cruises on which ${ }^{3} \mathrm{H}-\mathrm{TdR}$ incorporation was measured. (C) Depth profile of mean ratio of ${ }^{3} \mathrm{H}-\mathrm{TdR}_{\text {light: }}{ }^{3} \mathrm{H}-\mathrm{TdR}_{\text {dark }}$ during this study; error bars $= \pm \mathrm{SE}$ of time-mean ratio at each depth. Horizontal dotted lines = time-averaged (2000 to 2005) 1 and $0.1 \%$ PAR isopleths 
Table 3. Average proportion (\%) of ${ }^{3} \mathrm{H}$-label partitioned into nucleic acid and protein cellular subfractions following incubations with either ${ }^{3} \mathrm{H}$-leu or ${ }^{3} \mathrm{H}-\mathrm{TdR}$. Values are average percentage of nucleic acids or proteins extracted from picoplankton cell concentrates during 5 separate cruises to Stn ALOHA, with SDs in parentheses. NA = nucleic acid; percent ${ }^{3} \mathrm{H}\left(\right.$ disintegrations min $\left.^{-1}\right)$ extracted with hot 5\% TCA hydrolysis from cold 5\% TCA and 90\% ethanol insoluble cellular material. Protein $=$ percent ${ }^{3} \mathrm{H}$ (disintegrations $\mathrm{min}^{-1}$ ) extracted with $1 \mathrm{M} \mathrm{NaOH}$ hydrolysis from cold $5 \%$ TCA and $90 \%$ ethanol insoluble cellular material (see 'Methods and methods' for details). nd = no data

\begin{tabular}{|c|c|c|c|c|c|c|c|c|}
\hline $\begin{array}{l}\text { Depth } \\
\text { (m) }\end{array}$ & $\begin{array}{c}\text { NA } \\
{ }^{3} \mathrm{H}-\mathrm{leu}_{\text {light }}\end{array}$ & $\begin{array}{c}\text { Protein } \\
{ }^{3} \mathrm{H}-\text { leu }_{\text {light }}\end{array}$ & $\begin{array}{c}\text { NA } \\
{ }^{3} \mathrm{H}-\mathrm{leu}_{\mathrm{dark}}\end{array}$ & $\begin{array}{c}\text { Protein } \\
{ }^{3} \mathrm{H}-\mathrm{leu}_{\mathrm{dark}}\end{array}$ & $\begin{array}{c}\mathrm{NA} \\
{ }^{3} \mathrm{H}-\mathrm{TdR}_{\text {light }}\end{array}$ & $\begin{array}{c}\text { Protein } \\
{ }^{3} \mathrm{H}-\mathrm{TdR}_{\text {light }}\end{array}$ & $\begin{array}{c}\mathrm{NA} \\
{ }^{3} \mathrm{H}-\mathrm{TdR} \mathrm{R}_{\mathrm{dark}}\end{array}$ & $\begin{array}{c}\text { Protein } \\
{ }^{3} \mathrm{H}-\mathrm{TdR}_{\mathrm{dark}}\end{array}$ \\
\hline 5 & $4.6(4.4)$ & $97(1.8)$ & 4.3 (3.9) & $96(2.3)$ & $40(6.4)$ & $60(11)$ & $66(14)$ & 34 (19) \\
\hline 25 & $4.8(4.9)$ & $95(2.6)$ & $4.5(2.6)$ & $96(1.5)$ & 28 (10) & $72(17)$ & 62 (13) & 38 (18) \\
\hline 45 & $5.5(4.5)$ & $95(2.4)$ & $6.4(6.0)$ & $94(3.5)$ & 37 (11) & 63 (19) & $57(7.2)$ & 43 (10) \\
\hline 75 & $5.4(3.9)$ & 94 (2.6) & $5.8(4.1)$ & $94(2.4)$ & $43(6.4)$ & 57 (11) & $58(4.0)$ & $42(5.6)$ \\
\hline 100 & $5.0(3.7)$ & $95(2.5)$ & $5.5(3.6)$ & $94(2.1)$ & nd & nd & nd & nd \\
\hline 125 & $4.8(2.5)$ & $94(1.7)$ & $7.3(5.6)$ & 93 (3.3) & $32(6.5)$ & 68 (11) & 66 (15) & 34 (21) \\
\hline 150 & $7.5(3.9)$ & $94(1.2)$ & $6.8(3.4)$ & $93(2.0)$ & nd & nd & nd & nd \\
\hline 175 & $5.2(1.5)$ & $93(2.3)$ & $8.6(5.5)$ & 91 (3.1) & $33(7.2)$ & $67(12)$ & 64 (9.3) & 36 (13) \\
\hline
\end{tabular}

\section{DISCUSSION}

To elucidate time- and depth-dependent dynamics in rates of upper ocean HPP in the subtropical North Pacific Ocean, we measured rates of ${ }^{3} \mathrm{H}$-leu and ${ }^{3} \mathrm{H}$ TdR incorporation from depth profiles collected at Stn ALOHA on a series of cruises between April 2000 and August 2005. To our knowledge, these data represent the most extensive measurements of HPP in the oligotrophic North Pacific Ocean, and provide insight into the processes controlling variability in heterotrophic growth in this ecosystem. Moreover, the results of this study highlight the potentially important role that sunlight may play in regulating the growth of obligate and/or facultative heterotrophic picoplankton at Stn ALOHA.

Using a conversion factor of $1.5 \mathrm{~kg} \mathrm{C} \mathrm{mol}{ }^{-1}{ }^{3} \mathrm{H}$-leu incorporated (Kirchman 2001), the implied depth-integrated ( 0 to $175 \mathrm{~m}$ ) HPP derived from ${ }^{3} \mathrm{H}-\mathrm{leu}_{\text {light }}$ and ${ }^{3} \mathrm{H}-\mathrm{leu}_{\mathrm{dark}}$ incorporation rates averaged $0.41 \pm 0.19$ and $0.27 \pm 0.12 \mathrm{mmol} \mathrm{C} \mathrm{m}{ }^{-2} \mathrm{~h}^{-1}$, which represented 5 to $31 \%($ mean $=12 \%)$ and 3 to $17 \%($ mean $=7 \%)$ of the hourly rates of ${ }^{14} \mathrm{C}-\mathrm{PP}$, respectively (note that ${ }^{14} \mathrm{C}$-PP determinations do not include rates of DOC release). Due to the large percentage of non-specifically labeled acid- and base hydrolyzable material measured in the ${ }^{3} \mathrm{H}$-TdR incorporation experiments, we did not convert ${ }^{3} \mathrm{H}-\mathrm{TdR}$ incorporation rates into carbon production. Based on the carbon converted rates of ${ }^{3} \mathrm{H}-\mathrm{leu}$, the implied fraction of ${ }^{14} \mathrm{C}$-PP that supports obligate and/or facultative HPP at Stn ALOHA appears to be generally similar to other open ocean ecosystems (Ducklow \& Carlson 1992). For the seasonally oligotrophic Bermuda Atlantic Time series Study (BATS) in the Sargasso Sea, Carlson et al. (1996) estimated that 2 to $15 \%$ of the ${ }^{14} \mathrm{C}$-PP fueled HPP. More recently, in a review on bacterial biomass and productivity in open ocean ecosystems including the seasonally oligotrophic Sargasso Sea and the Arabian Sea, Ducklow (1999) estimated HPP was equivalent to $4-26 \%$ of ${ }^{14} \mathrm{C}$-derived estimates of PP. Recent estimates of gross primary production (GPP) at Stn ALOHA suggest the ${ }^{14} \mathrm{C}$-derived determinations of production underestimate gross production by more than a factor of 2 (Williams et al. 2004, Juranek \& Quay 2005). Such results suggest that HPP corresponds, on average, to a very small fraction $(<6 \%)$ of the total carbon produced by photoautotrophic growth, with the vast majority of organic matter production being respired in the upper ocean.

In a previous study at Stn ALOHA, we described the response of ${ }^{3} \mathrm{H}$-leu incorporation to light intensity (Church et al. 2004). We hypothesized that this response derived from photoheterotrophic or mixotrophic incorporation of the amino acid (leucine) by phototrophic picoplankton. Recent cultivation-dependent and -independent techniques suggest that diverse members of the oceanic picoplankton may be capable of mixotrophic and/or photoheterotrophic growth. Included among the list of potential mixotrophic picoplankton are diverse groups of $\alpha-, \beta$-, and $\gamma$-proteobacteria that encode the light-driven proton pump proteorhodopsin (Beja et al. 2000, 2001) aerobic anoxygenic phototrophs (Kolber et al. 2000, 2001), and facultative heterotrophy by cyanobacteria such as the genera Prochlorococcus and Synechococcus (Zubkov et al. 2003, 2004, Malmstrom et al. 2005). The results of the present study, when combined with our previous findings, confirm the stimulatory nature of PAR on ${ }^{3} \mathrm{H}$-leu incorporation throughout the euphotic zone at Stn ALOHA. However, despite observing consistent photostimulation of ${ }^{3} \mathrm{H}$-leu incorporation (a proxy for picoplankton protein production), rates of ${ }^{3} \mathrm{H}-\mathrm{TdR}$ incorporation into DNA did not demonstrate similar photostimulation. 
Although various light-driven processes could link light energy and HPP, the observation that rates of ${ }^{3} \mathrm{H}$-leu incorporation were stimulated by sunlight while rates of ${ }^{3} \mathrm{H}$-TdR were not provides additional information to help constrain possible causative mechanisms of the observed photoenhanced heterotrophic production. Several of the processes that could link (either directly or indirectly) HPP to sunlight include tightly coupled photosynthetic production of labile dissolved organic matter (DOM) and subsequent heterotrophic utilization of this DOM, photoheterotrophic and/or mixotrophic growth by picoplankton, and the photolytic alteration of DOM into biologically labile substrates. If rates of ${ }^{3} \mathrm{H}$-leu incorporation responded to sunlight as a result of a rapid coupling between photosynthetic production of labile DOM and heterotrophic production, or if the photostimulation of ${ }^{3} \mathrm{H}$-leu derived from photolytic transformation of DOM and subsequent stimulation of heterotrophic growth, we would have anticipated observing a photostimulatory effect on both ${ }^{3} \mathrm{H}$-TdR and ${ }^{3} \mathrm{H}$-leu incorporation. The differential effect of sunlight observed in the incorporation of these molecules suggests that either selected groups of phototrophic picoplankton incorporate the exogenous leucine without incorporating thymidine, or that sunlight selectively stimulates the production of protein without affecting DNA synthesis.

Examination of the recently completed genome sequences of several marine cyanobacterial isolates also sheds insight into one of the potential mechanisms underlying the observed responses in heterotrophic production to sunlight. Both high-light (MIT9312) and low-light (SS120, NATL2A, and MIT 9313) adapted strains of Prochlorococcus spp. encode putative ABC amino acid transport systems (Dufrense et al. 2003, Rocap et al. 2003). Similarly, the genome sequences of the oxyphotobacteria Synechococcus spp. (WH8102) (Palenik et al. 2003) and Trichodesmium erythraeum also encode putative amino acid transporters, but none of these oxyphotobacteria appear to contain genes that encode nucleoside transporters or thymidine kinases required to incorporate ${ }^{3} \mathrm{H}-\mathrm{TdR}$ into cellular DNA (Jeffrey \& Paul 1990). Consistent with these findings, a number of studies have concluded that eukaryotic algae and cyanobacteria appear unable to assimilate ${ }^{3} \mathrm{H}-\mathrm{TdR}$ at the nanomolar concentrations typically used in heterotrophic production assays (Pollard \& Moriarty 1984, Bern 1985, Jeffrey \& Paul 1990).

The ability of phototrophic picoplankton to assimilate DOM has been demonstrated in both laboratory cultures and natural field populations (Willey \& Waterbury 1989, Paerl 1991, Kamjunke \& Jahnichen 2000, Zubkov et al. 2003, 2004, Malmstrom et al. 2005). Using microautoradiography, Paerl (1991) demonstrated that pigmented picoplankton in oligotrophic regions of the Caribbean Sea were capable of assimilating a radiolabeled mixture of amino acids. More recently, Zubkov et al. $(2003,2004)$ found that in the oligotrophic regions of the subtropical and tropical Atlantic Ocean, Prochlorococcus spp. assemblages were capable of assimilating both L-methionine and L-leucine (Zubkov et al. 2004). Abundances of Prochlorococcus spp. at Stn ALOHA are considerably greater than in the Atlantic Ocean (Cavender-Bares et al. 2001) and the genus Prochlorococcus sustains a substantial fraction (80 to $90 \%$ ) of the measured photoautotrophic production at Stn ALOHA (Liu et al. 1997). The assimilation of organic nitrogen (in the form of amino acids) may supplement the nitrogen demands of these actively growing phototrophic assemblages in the nutrient-depleted upper ocean at Stn ALOHA. As a result, facultative heterotrophy by Prochlorococcus spp. could form an important component of upper ocean carbon and nitrogen cycling.

Evaluation of the relationships between in situ rates of $\Delta$ Leu and irradiance provided additional information about temporal and spatial variability in photostimulation of ${ }^{3} \mathrm{H}-\mathrm{leu}$ incorporation at Stn ALOHA. In the well-lit portion of the upper euphotic zone, rates of $\Delta$ Leu appeared independent of absolute light flux, but below $\sim 75 \mathrm{~m}$ depth rates of $\Delta$ Leu declined approximately linearly with exponential decreases in light intensity. The apparent saturation-like response in rates of $\Delta$ Leu with increasing irradiance suggests that, on average, above the depth of the 0.6 mol quanta $\mathrm{m}^{-2}$ $\mathrm{d}^{-1}$ isolume, ${ }^{3} \mathrm{H}$-leu incorporation rates were stimulated by sunlight, but the magnitude of the photostimulation was independent of light intensity. The similarity in responses of both ${ }^{3} \mathrm{H}$-leu and ${ }^{14} \mathrm{C}$-PP to irradiance in the deep euphotic zone $(>100 \mathrm{~m})$ could be driven by several mechanisms including (1) both ${ }^{3} \mathrm{H}$-leu and ${ }^{14} \mathrm{C}$ $\mathrm{PP}$ responding similarly to light at low irradiances, (2) ${ }^{14} \mathrm{C}$-PP and ${ }^{3} \mathrm{H}$-leu incorporation being tightly coupled in space and time in the deep euphotic zone, and/or (3) photostimulation of ${ }^{3} \mathrm{H}-\mathrm{leu}$ and ${ }^{14} \mathrm{C}-\mathrm{PP}$ controlled by the same phototrophic picoplankton assemblages.

The relative stimulation of ${ }^{3} \mathrm{H}-\mathrm{leu}$ incorporation $\left(\left[{ }^{3} \mathrm{H}-\right.\right.$ leu $\left._{\text {light }}{ }^{3} \mathrm{H}-\mathrm{leu}_{\mathrm{dark}}\right] /{ }^{3} \mathrm{H}-\mathrm{leu}_{\mathrm{dark}}$ ) by PAR was consistently greatest in the mid-euphotic zone, where light fluxes fell to $<5 \%$ of the surface irradiance, and daily PAR fluxes averaged between 0.21 and $1.7 \mathrm{mmol}$ quanta $\mathrm{m}^{-2} \mathrm{~d}^{-1}$. This region of the mid-euphotic zone intersects the top of the deep chlorophyll maximum (DCM). The persistence of the DCM at Stn ALOHA arises from a combination of increased pigmentation of the plankton assemblages growing at low light intensity, and may also reflect increased photoautotrophic biomass and growth near the top of the nitracline (Letelier et al. 1996, 2004). However, analyses of $\sim 14$ yr of monthly 
time series observations on Prochlorococcus spp. and Synechococcus spp. abundances at Stn ALOHA revealed no significant depth-dependent differences in the abundances of these cyanobacteria in the upper $75 \mathrm{~m}$ of the euphotic zone (1-way ANOVA, p > 0.05), but below the upper $75 \mathrm{~m}$ of the water, abundances of both Prochlorococcus and Synechococcus decline significantly (1-way ANOVA, $\mathrm{p}>0.05$ ). Thus, if the relative increases in photostimulated ${ }^{3} \mathrm{H}$-leu incorporation rates were driven by photoheterotrophic or mixotrophic growth by Prochlorococcus spp. or Synechococcus spp., the depth-dependence in relative photostimulation would not appear to result from increased cyanobacterial biomass in the lower regions of the euphotic zone.

The observed depth-dependent pattern of photostimulated ${ }^{3} \mathrm{H}$-leu incorporation is consistent with depth-dependent uptake of amino acids observed in the South Atlantic. Zubkov et al. (2004) found that lowlight adapted populations of Prochlorococcus spp. accounted for a larger fraction $(\sim 50 \%)$ of total amino acid uptake than high-light adapted populations $(\sim 25 \%)$. These authors identified declining cellspecific uptake of amino acids by high-light adapted Prochlorococcus spp. with increasing depth. We had previously reported that ${ }^{3} \mathrm{H}-\mathrm{leu}$ incorporation by picoplankton populations growing near the base of the photic zone at Stn ALOHA had a more pronounced response to irradiance than upper ocean picoplankton assemblages (Church et al. 2004). If the observed photostimulation of ${ }^{3} \mathrm{H}$-leu incorporation was driven by photoheterotrophic production by Prochlorococcus spp., our results suggest low-light adapted Prochlorococcus spp. ecotypes may account for a larger proportion of amino acid assimilation than high-light adapted assemblages.

The relatively low fraction of ${ }^{3} \mathrm{H}-\mathrm{TdR}$ incorporated into hot TCA soluble cellular material (assumed to represent DNA) may have arisen as a result of the long incubation times used during this study $(\sim 12.5 \mathrm{~h})$ and increased likelihood of intracellular recycling (Carmen et al. 1988). Alternatively, the high proportion of nonspecific labeling may have been due to an artifact of the methods we used to separate DNA and protein (Servais et al. 1987, Torréton \& Bouvy 1991). From the results of the present study, we cannot determine whether the high proportion of ${ }^{3} \mathrm{H}$ retrieved with the base hydrolyzable material represents a methodological artifact or reflects non-specific catabolism of ${ }^{3} \mathrm{H}-\mathrm{TdR}$. However, these experiments revealed that picoplankton incorporation of ${ }^{3} \mathrm{H}-\mathrm{TdR}$ (whether specifically into DNA or nonspecifically into protein) did not demonstrate the same photostimulation by sunlight as observed for ${ }^{3} \mathrm{H}$-leu incorporation rates.
Evaluating rates of ${ }^{3} \mathrm{H}$-leu and ${ }^{3} \mathrm{H}$-TdR incorporation at Stn ALOHA provided a unique look at the spatial and temporal variability in HPP in the oligotrophic North Pacific Ocean. In general, both the temporal variability and absolute rates of HPP at Stn ALOHA appear similar to those of other oligotrophic oceanic ecosystems; however, upper ocean picoplankton incorporation of ${ }^{3} \mathrm{H}$-leu demonstrated significant stimulation by PAR. The photostimulation of ${ }^{3} \mathrm{H}-\mathrm{leu}$ and lack of stimulation of ${ }^{3} \mathrm{H}-\mathrm{TdR}$ incorporation emphasizes the potentially important role that facultative heterotrophs, including cyanobacteria, may play at Stn ALOHA and provides further insight into light-driven processes that need to be considered when measuring the productivity of the ocean ecosystems.

Acknowledgements. We thank the captains and crew of the RV 'Kaimikai-O-Kanaloa', and the RV 'Kilo Manoa' for safe operation of these research vessels. We appreciate the dedicated efforts of the technical staff at the Hawaii Ocean Timeseries program. The contributions of 3 anonymous reviewers greatly improved this manuscript. Funding for this project was provided by NSF grants to D.M.K. (OCE96-17409), R.M.L. (OCE03-26419), and H.W.D. (OCE98-19581). Additional support from the Gordon and Betty Moore Foundation to D.M.K. helped make this study possible. This is SOEST contribution 6993.

\section{LITERATURE CITED}

Azam F, Fenchel T, Field JG, Gray JS, Meyer-Reil LA, Thingstad F (1983) The ecological role of water-column microbes in the sea. Mar Ecol Prog Ser 10:257-263

Béjà O, Aravind L, Koonin EV, Suzuki MT and 8 others (2000) Bacterial rhodopsin: evidence for a new type of phototrophy in the sea. Science 289:1902-1906

Béjà O, Spudich EN, Spudich JL, Leclerc M, DeLong EF (2001) Proteorhodopsin phototrophy in the ocean. Nature 411:786-789

Béjà $\mathrm{O}$, Suzuki MT, Heidelberg JF, Nelson WC and 5 others (2002) Unsuspected diversity among marine aerobic anoxygenic phototrophs. Nature 415:630-633

Bern L (1985) Autoradiographic studies of methyl- ${ }^{3} \mathrm{H}$-thymidine incorporation in a cyanobacterium Microcystis wesenbergii-bacterium association and in selected algae and bacteria. Appl Environ Microbiol 49:232-233

Campbell L, Vaulot D (1993) Photosynthetic picoplankton community structure in the subtropical North Pacific Ocean near Hawaii (Stn ALOHA). Deep-Sea Res I 40:2043-2060

Carlson CA, Ducklow HW (1996) Growth of bacterioplankton and consumption of dissolved organic carbon in the Sargasso Sea. Aquat Microb Ecol 10:69-85

Carlson CA, Ducklow HW, Sleeter TD (1996) Stocks and dynamics of bacterioplankton in the northwestern Sargasso Sea. Deep-Sea Res II 43:491-515

Carmen KR, Dobbs FC, Guckert JB (1988) Consequences of thymidine catabolism for estimates of bacterial production: an example from a coastal marine sediment. Limnol Oceanogr 33:1595-1606

Caron DA, Dam HG, Kremer P, Lessard EJ and 6 others (1995) 
The contribution of microorganisms to particulate carbon and nitrogen in surface waters of the Sargasso Sea near Bermuda. Deep-Sea Res I 42:943-972

Cavender-Bares KK, Karl DM, Chisholm SW (2001) Nutrient gradients in the western North Atlantic Ocean: relationship to microbial community structure and comparison to patterns in the Pacific Ocean. Deep-Sea Res I 48: 2373-2395

Church MJ, Ducklow HW, Karl DM (2004) Light-dependence of ${ }^{3} \mathrm{H}$-leucine incorporation in the oligotrophic North Pacific Ocean. Appl Environ Microbiol 70:4079-4087

Ducklow HW (1983) Production and fate of bacteria in the oceans. BioScience 33:494-501

Ducklow HW (1999) The bacterial component of the oceanic euphotic zone. FEMS Microbiol Ecol 30:1-10

Ducklow HW, Carlson CA (1992) Oceanic bacterial production. Adv Microb Ecol 12:113-181

Ducklow HW, Kirchman DL, Quinby HL (1992) Bacterioplankton cell growth and macromolecular synthesis in seawater cultures during the North Atlantic spring phytoplankton bloom, May 1989. Microb Ecol 24:125-144

Fuhrman JA, Sleeter TD, Carlson CA, Proctor LM (1989) Dominance of bacterial biomass in the Sargasso Sea and its ecological implications. Mar Ecol Prog Ser 57:207-217

Gasol JM, del Giorgio PA, Duarte CM (1997) Biomass distribution in marine planktonic communities. Limnol Oceanogr 42:1353-1363

Goldman JC (1988) Spatial and temporal discontinuities of biological processes in pelagic surface waters. In: Rothschild BJ (ed) Towards a theory on biological and physical processes in the world ocean. Kluwer Academic, Dordrecht, p 273-296

Jeffrey WH, Paul JH (1990) Thymidine uptake, thymidine incorporation, and thymidine kinase-activity in marine bacterium isolates. Appl Environ Microbiol 56:1367-1372

Juranek LW, Quay PD (2005) In vitro and in situ gross primary and net community production in the North Pacific Subtropical Gyre using labeled and natural abundance isotopes of dissolved $\mathrm{O}_{2}$. Global Biogeochem Cycles 19:GB3009, doi:10.1029/2004GB002384

Kamjunke N, Jahnichen S (2000) Leucine incorporation by Microcystis aeruginosa. Limnol Oceanogr 45:741-743

Karl DM (1982) Selected nucleic acid precursors in studies of aquatic microbial ecology. Appl Environ Microbiol 44: 891-902

Karl DM, Lukas R (1996) The Hawaii Ocean Time-series (HOT) program: background, rationale and field implementation. Deep-Sea Res II 43:129-156

Karl DM, Christian JR, Dore JE, Hebel DV, Letelier RM, Tupas LM, Winn CD (1996) Seasonal and interannual variability in primary production and particle flux at Stn ALOHA. Deep-Sea Res II 43:539-568

Kirchman D (2001) Measuring bacterial biomass production and growth rates from leucine incorporation in natural aquatic environments. Methods Microbiol 30:227-237

Kirchman D, Knees E, Hodson R (1985) Leucine incorporation and its potential as a measure of protein-synthesis by bacteria in natural aquatic systems. Appl Environ Microbiol 49:599-607

Kolber ZS, Van Dover CL, Niederman RA, Falkowski PG (2000) Bacterial photosynthesis in surface waters of the open ocean. Nature 407:177-179

Kolber ZS, Plumley FG, Lang AS, Beatty JT and 6 others (2001) Contribution of aerobic photoheterotrophic bacteria to the carbon cycle in the ocean. Science 292: $2492-2495$
Laws EA (2003) Partitioning of microbial biomass in pelagic aquatic communities: maximum resiliency as a food web organizing construct. Aquat Microb Ecol 32:1-10

Letelier RM, Dore JE, Winn CD, Karl DM (1996) Seasonal and interannual variations in photosynthetic carbon assimilation at Stn ALOHA. Deep-Sea Res II 43:467-490

Letelier RM, Karl DM, Abbott MR, Bidigare RR (2004) Light driven seasonal patterns of chlorophyll and nitrate in the lower euphotic zone of the North Pacific Subtropical Gyre. Limnol Oceanogr 49:508-519

Li WKW, Dickie PM, Irwin BD, Wood AM (1992) Biomass of bacteria, cyanobacteria, prochlorophytes and photosynthetic eukaryotes in the Sargasso Sea. Deep-Sea Res I 39:501-519

Li WKW, Rao DVS, Harrison WG, Smith JC, Cullen JJ, Irwin B, Platt T (1983) Autotrophic picoplankton in the tropical ocean. Science 219:292-295

Liu HB, Nolla HA, Campbell L (1997) Prochlorococcus spp. growth rate and contribution to primary production in the equatorial and subtropical North Pacific Ocean. Aquat Microb Ecol 12:39-47

Malmstrom RR, Kiene RP, Vila M, Kirchman DL (2005) Dimethylsulfoniopropionate (DMSP) assimilation by Synechococcus in the Gulf of Mexico and northwest Atlantic Ocean. Limnol Oceanogr 50:1924-1931

Michaels AF, Knap AH, Dow RL, Gundersen K and 8 others (1994) Seasonal patterns of ocean biogeochemistry at the United-States JGOFS Bermuda Atlantic Time-Series study site. Deep-Sea Res I 41:1013-1038

Monger BC, Landry MR (1993) Flow cytometric analysis of marine-bacteria with Hoechst 33342. Appl Environ Microbiol 59:905-911

Monterey G, Levitus S (1997) Seasonal variability of mixed layer depth for the world ocean. NOAA Atlas NESDIS 14, US Government Printing Office, Washington, DC

Paerl HW (1991) Ecophysiological and trophic implications of light-stimulated amino acid utilization in marine picoplankton. Appl Environ Microbiol 57:473-479

Palenik B, Brahamsha B, Larimer FW, Land M and 11 others (2003) The genome of a motile marine Synechococcus. Nature 424:1037-1042

Platt T, Jassby AD (1976) Relationship between photosynthesis and light for natural assemblages of coastal marinephytoplankton. J Phycol 12:421-430

Pollard PC, Moriarty DJW (1984) Validity of the tritiated thymidine method for estimating bacterial growth ratemeasurement of isotope dilution during DNA synthesis. Appl Environ Microbiol 48:1076-1083

Pomeroy LR (1974) The ocean's food web: a changing paradigm. BioScience 9:499-504

Sakshaug E, Bricaud A, Dandonneau Y, Falkowski PG and 5 others (1997) Parameters of photosynthesis: definitions, theory and interpretation of results. J Plankton Res 19: $1637-1670$

Servais P, Martinez J, Billen G, Vives-Rego J (1987) Determining $\left[{ }^{3} \mathrm{H}\right]$-thymidine incorporation into bacterioplankton DNA: improvement of the method by DNase treatment. Appl Environ Microbiol 53:1977-1979

Torréton JP, Bouvy M (1991) Estimating bacterial-DNA synthesis from $\left({ }^{3} \mathrm{H}\right)$-thymidine incorporation-discrepancies among macromolecular extraction procedures. Limnol Oceanogr 36:299-306

Vaulot D (1989) CYTOPC: processing software for flow cytometric data. Signal Noise 2:8

Willey JM, Waterbury JB (1989) Chemotaxis toward nitrogenous compounds by swimming strains of marine Synechococcus spp. Appl Environ Microbiol 55:1888-1894 
Williams PJleB, Morris PJ, Karl DM (2004) Net community production and metabolic balance at the oligotrophic site: Stn ALOHA. Deep-Sea Res I 51:1563-1578

Zubkov MV, Sleigh MA, Burkill PH, Leakey RJG (2000) Picoplankton community structure on the Atlantic Meridional Transect: a comparison between seasons. Prog Oceanogr 45:369-386

Zubkov MV, Fuchs BM, Tarran GA, Burkill PH, Amann R

Editorial responsibility: Jed Fuhrman,

Los Angeles, California, USA
(2003) High rate of uptake of organic nitrogen compounds by Prochlorococcus spp. cyanobacteria as a key to their dominance in oligotrophic oceanic waters. Appl Environ Microbiol 69:1299-1304

Zubkov MV, Tarran GA, Fuchs BM (2004) Depth related amino acid uptake by Prochlorococcus spp. cyanobacteria in the Southern Atlantic tropical gyre. FEMS Microbiol Ecol 50:153-161

Submitted: May 30, 2004; Accepted: August 5, 2006

Proofs received from author(s): October 10, 2006 